\title{
SILENCIAMENTOS, FORMAÇÃO E ARTES CÊNICAS: O ESVAZIAMENTO DA EXPERIÊNCIA ${ }^{1}$
}

Vanessa Nogueira de Oliveira ${ }^{2}$

\section{RESUMO}

A partir de memórias narradas e gesticuladas, em constante dialogo com as experiências vivenciadas durante o ato formativo, com este artigo procura-se deixar em evidencia processos de silenciamentos vivenciados em certos modelos e práticas formativas no âmbito do Curso de Artes Cênicas: Teatro da Universidade Federal do Acre. Tendo como referência os Estudos Culturais, dialoga-se com falas marcadas por constantes tensões entre alunos e professores, evidenciadas a partir das relações hierarquizantes dentro da sala de aula. No trânsito e encontro de diferentes trajetórias ganha evidência o quanto a escola e, nesse caso, a universidade exercem um papel crucial na transformação das memórias e subjetividades humanas, interditando corpos em contextos nos quais a experiência é inferiorizada em detrimento da teoria que deve ser incorporada até o término do curso.

\section{PALAVRAS-CHAVE}

Corpo. Trajetória. Memória. Silenciamentos. Experiência.

\section{PRIMEIRAS PALAVRAS}

A pesquisa que deu origem a este texto fez parte de um processo de retorno para dentro dos muros acadêmicos, uma busca para compreender de que modo, durante o processo de formação dos sujeitos, a academia contribui para silenciar suas experiências. Para iniciar o processo de pesquisa, fizemos um estudo sobre a inserção obrigatória do ensino de artes no currículo escolar brasileiro e entrevistamos o principal ativista e articulado da criação dos cursos de artes na Universidade Federal do Acre (Ufac), o artista plástico e intelectual Dalmir Ferreira. Na entrevista, procuramos compreender, dentre outras coisas, o porque da escolha ter recaído nas linguagens das artes cênicas e musicais.

Após o contato inicial com Dalmir Ferreira, iniciamos o retorno para dentro dos muros universitários, observamos algumas aulas no curso e selecionamos os estudantes. Ao todo, convidamos 19 estudantes, dos quais, apenas 10 aceitaram participar da pesquisa, os outros estudantes ou se recusaram ou não compareceram ao local marcado. Assim, o recorte aqui apresentando traz parte das memórias de nossos depoentes, agora re-significadas a partir do contato com a universidade.

Para realização da investigação, escolhemos a narrativa (história) oral como metodologia e, entre os diversos estudiosos da oralidade, optamos por dialogar com as contribuições de Alessandro Portelli (2009). Com ele, passamos a compreender que a entrevista é um ato efêmero, visto que, no momento da transcrição, os olhares já não se encontram, as falas são revisitadas e transformadas sob a visão e a leitura de uma das partes: o pesquisador. Evidencia-se, desse modo, uma tensão entre a voz e a escrita.

Durante todo o percurso da pesquisa, buscamos considerar o fato de que "aquilo que criamos é um texto dialógico de múltiplas vozes e múltiplas interpretações; as muitas interpretações dos entrevistados, nossas interpretações e as interpretações dos leitores” (PORTELLI, 1997, p. 27). Assim, cada um dos depoentes envolvidos durante o processo pode, a partir das suas próprias experiências, criar novos significados. Desse modo, destacamos que as análises aqui apresentadas não são as únicas possíveis, por isso optamos por assinalar as falas dos sujeitos, para permitir que o leitor tenha contato com as transcrições no corpo do texto e, talvez, com elas crie novas possibilidades de leitura, escrita e interpretação.

O diálogo se dá com sujeitos inacabados, sujeitos mutáveis, em constantes processos

1 Texto originalmente apresentado como parte da Dissertação de Mestrado "Filtros e margens do corpo: trajetórias de alunos do curso de Artes Cênicas - Teatro na Amazônia acreana", defendida junto ao Programa de Pós-Graduação em Letras: Linguagem e Identidade da Universidade Federal do Acre.

2 Mestre em Letras: Linguagem e Identidade pela Universidade Federal do Acre e Professora da Educação Básica vinculada à Secretaria de Estado e Educação do Acre. 
de transformação. Nós não somos, nós estamos. Estamos em movimento, em trânsito, em constante mudança. Nas palavras de Édouard Glissant, "chegamos a um momento da vida das humanidades em que o ser humano começa a aceitar a ideia de que ele mesmo está em perpétuo processo. Ele não é ser, mas sendo e que como todo sendo, muda". O autor conclui: "não somos uma entidade absoluta, mas sim um sendo mutável” (GLISSANT, 2005, p. 33). Constatamos que "as recordações podem ser semelhantes, contraditórias ou sobrepostas. Porém, em hipótese alguma, as lembranças de duas pessoas são (...) exatamente iguais" (PORTELLI, 1997, p. 16). Diante dos fragmentos das trajetórias dos sujeitos, organizamos um mosaico de lembranças, em constante diálogo com os teóricos lidos e analisados durante o processo.

As mudanças e transformações sociais acontecem no corpo. É o corpo que muda e é transformado. O corpo que foi e ainda é negligenciado na sociedade ocidental de tradição platônica cristã. Nela, há negação do corpo. O corpo é negado, principalmente, quando não reconhecemos a multiplicidade dos corpos e, consequentemente, de opiniões, pontos de vista, percepções, desejos, sonhos, experiências, estéticas, histórias. Quando negamos o corpo, negamos o direito à vida, uma vez que, de acordo com Cardim e sua leitura de Nietzsche, viver é "inventar, interpretar, avaliar, pesar. Se damos as costas à vida, ao corpo e ao mundo em prol das ideias de estilo platônico ou mesmo em benefício de um mundo ainda por vir, trata-se de compreender que, neste momento, negamos a pluralidade infinita de interpretações possíveis (CARDIM, 2009, p. 76). Nessa direção, buscamos perceber o corpo dos sujeitos como corpo vivo. Um corpo que é, ao mesmo tempo, "passivo" e "ativo", que é isto e aquilo, ou melhor, um corpo que é sempre múltiplo e, no dizer do poeta, "inclassificável”.

É com a ideia de corpo vivo que dialogamos. Em nosso estudo, buscamos evidenciar as ambiguidades dos sujeitos que são/foram capazes de perceber os aspectos inerentes da existência humana, pois não somos sujeitos estagnados. Mudamos e nos deslocamos com o tempo e através do tempo. Tempo impalpável, mediador de memória e transformador de experiências. Tempo da narrativa, da criação e do próprio homem. Tempo que deixa marcas no corpo dos sujeitos, pois "a vida humana está inteiramente apoiada sobre o corpo e associada às relações intersubjetivas” (CARDIM, 2009, p. 99) e é nessas relações que nos situamos.

Relações corpóreas evidenciam a submissão e também a desobediência. Questões, por vezes, hierarquizadas: “o sentido dessa hierarquia está em que, através dela, há ao mesmo tempo divisão e ligação das partes. Haverá divisão quando se tratar de oposição e luta. Haverá ligação quando for a vez da integração" (CARDIM, 2009, p. 79). Cardim afirma que o "corpo humano é entendido (...) como uma sociedade constituída em luta entre si, mas também em integração. Nessa consideração do corpo como estrutura social, ora uns vencem, ora outros" (CARDIM, 2009, p. 79-80). Por mais que os corpos joguem de lados opostos, eles se comunicam, se tocam, se chocam e se transformam também através desse contato.

Assumimos e dialogamos com a noção de "crioulização", com o "ser sendo" de Glissant e é este direito de ser mutável que reivindicamos. Em diálogo com Stuart Hall (2003), compreendemos que tudo está intimamente relacionado com a experiência e essa é de suma importância para apreendermos o significativo campo de reflexão dos estudos culturais, que têm a cultura como categoria de análise. Cultura pensada como toda forma de ser e de viver a experiência humana.

Os depoentes desta pesquisa são marcados pela experiência do que foi vivido e, quando por nós provocadas, suas palavras são marcadas por suas práticas culturais e por suas subjetividades, tornando-se, em geral, inalcançáveis e incompreensíveis, principalmente, quando não conhecemos o local de onde eles falam. Local esse pautado por sua experiência. Experiência pensada na perspectiva benjaminiana, como o que foi vivido, interpretado, pensado, ouvido, imaginado. 
Para afirmarmos o indizível, recorremos às vozes dos nossos atores, estudantes do curso de teatro, moradores da Amazônia acreana, homens e mulheres marcados por ricas experiências de vida, que entraram em choque com discursos enclausurados e encapsuladores. Eles saíram de seus locais de moradias para ingressar na Ufac e realizar um sonho e passaram a viver o paradoxo de ver negadas suas próprias trajetórias. São silenciados em um curso que não atenta para a diversidade das experiências de seus alunos, que, muitas vezes, são esvaziadas de sentido porque as teorias disciplinadoras devem ser consumidas e aprendidas para ser aplicada na escola e na sociedade.

\section{TRÂNSITOS DE EXPERIÊNCIAS}

No dinâmico processo da pesquisa, ouvimos vozes no vivenciar de performances, gestualidades, virtualidades de corpos inquietos, de sujeitos sociais capazes de transformar em palavras simples a complexidade de suas trajetórias: um verdadeiro trânsito de experiências, de seres diaspóricos, no sentido mesmo cunhado por Hall, isto é, de sujeitos de muitos tempos e lugares, de deslocamentos constantes, de certezas e incertezas, seguranças e inseguranças no continuum de suas existências. As mudanças de cidades, a escola, o trabalho, a busca de profissionalização, as muitas descobertas, as ilusões e desilusões, a vontade de continuar, de ir em frente, as práticas culturais e os processos de transformação identitárias, tudo em movimento no sendo de suas existências. Aqui, procuramos dialogar com essas extraordinárias pessoas, suas vozes, gestos, pontos de vista.

No momento da entre-vista, embora tivesse ingressado no Curso de Artes Cênicas há pouco tempo, Diana de Araújo já se dera conta de como as experiências individuais dos sujeitos sociais perdem espaço, sendo restringidas e mesmo aniquiladas. Em suas primeiras palavras "o teatro não é nada do que os professores falam, porque eu tenho minha própria visão de teatro. O teatro para mim é você se libertar, é estar livre. É fazer aquilo que você quer. (...) Nisso se define o teatro (ARAÚJO, 2014). Em outras palavras, liberdade de expressão e das vontades realizáveis através do corpo. No entanto, Diana de Araújo tem de esquecer, pelo menos por enquanto, sua percepção sobre o teatro, uma vez que o que ela viveu fora da universidade não condiz com aquilo que os autores manifestam e com o que seus professores ensinam. Assim a vivência do sujeito, em vez de ser utilizada para criar possibilidades de conceituação, é negada e seus corpos são mutilados em favor de uma experiência acadêmica. Nesse processo, o estudante tem, mais uma vez, contestada a existência de um corpo. Um corpo vivo que é coisificado para se adequar à vida em sociedade.

A partir de nossas próprias experiências e no diálogo com os depoentes da pesquisa, apreendemos que é com esse "corpo coisa" que nos deparamos no interior do Curso de Artes Cênicas da Ufac. Corpo que é colocado dentro de padrões estereotipados, corpo impactado pela materialização de um discurso "tal como surge nas páginas de Platão e Descartes”, no dizer de Cardim, exigindo "um alto preço a ser pago: esquecimento sistemático, ódio, negação do corpo e dos sentidos, logo, da própria vida". Um corpo envolvido dentro de um sistema de controle e repressão no qual "a negação da vida chega ao limite quando, a duras penas, um silêncio sepulcral é imposto à vida” (CARDIM, 2009, p. 74). É a essa negação do sujeito que nos referimos ao longo do texto, pois observamos que há materialização daquilo que Foucault chamou de corpos dóceis: "é dócil um corpo que pode ser submetido, que pode ser utilizado, que pode ser transformado e aperfeiçoado" (FOUCAULT, 1987, p. 118). Para alcançar a perfeição do corpo, é preciso que haja métodos e que por intermédio dele se trabalhe com as "disciplinas" e com elas sejam impostas uma "relação de docilidade-utilidade" (FOUCAULT, 1987, p. 118).

Ao relembrar esses moldes aos quais o corpo deveria se encaixar, Alan Saldanha menciona os discursos recorrentes, principalmente, durante as aulas "práticas", nas quais o corpo é o objeto de trabalho do "aluno/ator/professor/pesquisador". Nessas aulas, os professores "estimulavam" os 
alunos a saltarem uma cambalhota, a improvisar, a se expor diante de outros colegas. Ele diz que sentia dificuldade nessas atividades, primeiramente, porque acreditava ser aquilo "ridículo" e "desnecessário" e, depois, porque era tímido. Diante da recusa e resistência em fazer o exercício, ouvia dos seus professores:

'Você realmente quer isso? Vocês realmente querem fazer isso? Não é fácill Você tem que se entregar! Você tem que fazer!' Então aquilo me intimidava mais ainda. Tipo: vocês querem realmente fazer isso? Essa pergunta estava sempre voltando. Quando não era por um professor era por outro. Aí eu perguntava: era só isso? (SALDANHA, 2013).

Se essa indagação deveria soar como uma motivação, notamos que ela soava mais como intimidação. $\mathrm{O}$ aluno demonstra inquietude e falta de compreensão diante da questão colocada pelos professores. "Era só isso?", se pergunta ao recorrer à sua memória. Notemos ainda que, na fala de Alan Saldanha, os maiores entraves aconteciam durante a realização das aulas "práticas", onde as limitações e as dificuldades físicas se tornavam mais evidentes. Com isso, percebemos também que, nessas situações, em vez de conduzirem seus alunos e estimulá-los para que, juntos, pudessem superar suas limitações, os professores provocavam seus estudantes com discursos como "você realmente quer isso?". Essa pergunta era percebida pelos alunos de diversas maneiras, mas eles sempre se questionavam sobre a continuação ou não do curso.

É no corpo dos que se imprime a "identidade" de licenciado em artes cênicas - teatro. No corpo o sujeito é transformado, sendo-lhe imposto um novo modo de pensar e de aprender dentro da universidade que tende a enclausurar os estudantes em sua área de formação. Porém, o corpo do sujeito que pensa, questiona e se movimenta não é totalmente enclausurável. Nesse sentido, dialogamos com Michel de Certeau (2011), com seu "homem ordinário", sujeito que burla, que cria suas maneiras/táticas de sobrevivência. Com Certeau, visualizamos as possibilidades que podem ser utilizadas por nossos depoentes durante o processo formativo que não se restringe apenas à vida universitária, uma vez que o sujeito utiliza essas possibilidades para criar suas táticas de sobrevivência na vida em sociedade. Ademais, entendemos que nossos depoentes são múltiplos e recebem as indagações feitas por seus professores de maneiras diversas.

Apresentamos as falas/depoimentos/gestos dos sujeitos da pesquisa, em seus - nossos - constantes diálogos com o passado. É à memória deles que recorremos, memória de um tempo que já não é o que foi. Memória que, para nós, "é um processo, algo que está acontecendo agora, do qual todos participamos" (PORTELLI, 2000, p. 69) e que é objeto de estudo da história oral. Durante nossos diálogos, convidamos os depoentes a narrarem suas trajetórias de vida desde a infância, tempo em que eram guiados pelas mãos dos seus pais, tempo em que a preocupação com o futuro era inexistente, tempo em que suas vontades e pensamentos eram transportados pelo embalo de práticas e afazeres cotidianos marcados pela presença da floresta ou do viver em cidades/floresta, algo peculiar nas Amazônias.

Ao revisitar sua memória, Alan Saldanha relata:

Antes [da escola], a gente vivia indo para as colônias, para os sítios e eu tenho muitas lembranças
da minha vida nas colônias com a minha mãe. Acordava de madrugada, às vezes, ia a pé, acho que
andava uns cinco ou seis quilômetros da cidade para o ramal da Piçarreira e eu andava muito tempo
com ela por lá. Eu me lembro de pescarias que a gente ia (SALDANHA, 2013).

Se antes de ir para a escola sua rotina era controlada pelos pais e suas profissões na cidade, com a ida para escola, o indivíduo é submetido ao ambiente de controle de corpos, tempo e mente, pois, com a rotina escolar apreende novos modos de fazer e, assim, já não brinca, nem se "movimenta" de acordo com sua vontade, mas de acordo com as regras preestabelecidas na escola onde, a maior parte do tempo, o controle é exercido pela figura do professor: é a ele que o aluno deve obedecer, responder, apresentar-se. Quando se ausenta da sala de aula, mais uma vez, o estudante se mantém sob os olhos 
daquele que o observa e o controla; controle então exercido pela figura do inspetor de corredor. Nesse processo de controle e obediência, o sujeito é treinado para o mercado de trabalho.

A escola é, destarte, nas falas dos nossos depoentes, o local de ruptura com a família e com o espaço. Suas falas e seu tempo são controlados juntamente com seus corpos. A primeira reação ante o mundo novo do controle e a ruptura com o local da sua tenra infância se fazem presente no choro em razão da insegurança sentida na ausência dos pais. Sobre seu primeiro dia de aula, Alan Saldanha conta: "lembro que chorei (...). Com saudade do pai e da mãe, eu comecei a chorar..." (SALDANHA, 2013). Ao continuar sua narrativa, ele se dá conta de que "com a escola, [a gente] realmente muda; tem aquele horário da manhã que você vai para aula. Já perdi mais o contato com o campo. E realmente passei a ter aquela rotina" (SALDANHA, 2013).

Ressaltamos que é de um "tempo passado" que nossos depoentes falam. Em suas narrativas, eles trazem a imagem de uma floresta desconhecida para a maioria das crianças contemporâneas. Em suas lembranças, eles falam de um lugar que, há vinte anos, não estava totalmente tomado por redes de energia elétrica, estradas de asfalto, automóveis, escolas. Os "lugares da infância" ainda não haviam sido invadidos pelo "tempo" da cidade, onde o artefato é o responsável por lembrar aos homens a hora de cumprir suas rotinas. É também esse tempo distante que os depoentes narram ao recordar da escola. Eles não falam da escola de agora, falam da escola "daquele tempo", de quando eles tinham seis ou sete anos de idade.

Tempo conflituoso quando defensores da educação e da escola pautam suas críticas nessas lembranças, comparando o que eles viveram "naquele tempo" com aquilo que temos na escola "agora". Isso se torna conflituoso porque, por inúmeras vezes, nos esquecemos de que o tempo é uma narrativa, e, portanto, objeto da imaginação do homem. Narrativa não linear que, entre uma lembrança e outra, deixa claro os momentos de ruptura. O próprio Alan Saldanha, no decorrer do nosso encontro, descreve um desses momentos vivenciados na escola. Ele relata que, em um dia, em uma aula, a professora pediu para os alunos citarem as profissões que conheciam. Para isso, ela sugeriu que se baseassem na profissão dos seus pais.

Lembro que, quando eu estava na primeira série, assim, lá no João Pedro II, a professora falou assim:
'vamos nomear as profissões. Qual é a profissão dos seus pais?. Nessa época, o pai vendia banana, e
eu gostava de ir buscar banana com ele lá no barranco do rio, na Sobral. Nessa época, a gente morava
na Sobral. A gente ia buscar banana, melancia. Eu gostava muito daquilo, né? Eu admirava muito
assim. Até hoje eu admiro. Mas eu admirava muito aquilo que ele fazia. Aí os moleques começaram
a dizer: 'ah, meu pai é motorista'. 'Meu pai é advogado'. 'Meu pai é enfermeiro e tal'. Aí eu fui e
falei ‘bananeiro', bem alto. Eu só ouvi vaias. A galera vaiando. A professora se colocou de pé e falou:
'silêncio'! É uma profissão aqui tão digna quanto qualquer uma daquelas que vocês falaram. Aí foi lá
no quadro e colocou assim bem grande: “bananeiro”. Mas eu fiquei ainda impactado com aquilo,
porque eu não esperava aquela reação (SALDANHA, 2013).

Ele não havia se sentido constrangido com a profissão do pai até aquele momento. Para ele, ir com o pai para o barranco do rio era motivo de diversão. Ele se orgulhava do trabalho do pai. $\mathrm{Na}$ sua cabeça de criança, ouvir a vaia dos colegas foi uma ruptura entre seu mundo particular e o mundo dos outros. Embora a professora tenha tentado minimizar a situação, Alan Saldanha ficou impactado com a reação dos seus colegas. Como o trabalho do seu pai - para ele tão grandioso, tão divertido - podia ser motivo de piada?

A reação das crianças ante a profissão do pai de Alan Saldanha fez com que ele tivesse contato com a complexa relação entre os sujeitos. Sujeitos que, desde muito jovens, aprendem a qualificar e desqualificar seus semelhantes. É nessa relação complexa que Alan Saldanha, talvez, tenha se dado conta, pela primeira vez, da sua condição social. Até aquele momento, seu pai era apenas um trabalhador comum, que utilizava sua força de trabalho para sustentar a família; para ele, a profissão do pai era tão 
digna quanto qualquer outra. Por isso, naquele momento, ele não entendeu a reação dos seus colegas.

A escola como instituição de ensino ocasionou em nossos depoentes momentos embaraçosos e dolorosos. Escola que surge como obrigação para os homens do campo. Os pais dos nossos depoentes que ainda viviam nas colônias, muitas vezes, se sentiam na obrigação de enviar seus filhos para estudar na cidade. As crianças iam a contragosto para a casa de parentes ou amigos da família para que pudessem estudar. Nesse novo lar, a criança de outrora, para compensar os favores recebidos, auxiliava os adultos nos afazeres domésticos.

Maria Francisca da Silva foi por vontade própria para a cidade, pois queria estudar. Ela relata sua experiência na cidade de Rio Branco, quando conseguiu, por intermédio da tia, uma casa para morar.

Minha tia falou com uma amiga dela que já morava aqui em Rio Branco, para ver se eu não podia ficar na casa dela para terminar o ensino médio. Só que eu tinha que trabalhar também, porque eu estava na casa dela, mas não era de graça. Eu tinha que ganhar minha passagem de ônibus, minha farda, meu material escolar. Então, eu ajudava nos trabalhos da casa, cuidava dos filhos dela e foi indo (SILVA, 2013).

Durante o tempo em que morou na casa dessa senhora sem nome, "a amiga da tia", ela se tornou a babá dos filhos da sua benfeitora. Não há porque ser grata a essa mulher, uma vez que ela não estava lá de graça. Maria Francisca da Silva trabalhava para garantir os favores recebidos: casa, comida e a oportunidade de se manter na cidade de Rio Branco. Ao concluir o ensino médio, ela decidiu não retornar mais para a casa dos pais em Cruzeiro do Sul (AC), a cidade em que cresceu. O lugar do encontro com o campo e com a trajetória dos seus pais se tornou apenas um ponto de passagem. Maria Francisca da Silva é agora apenas um visitante de um passado que lembra e atualiza no presente.

Sabemos que, mesmo buscando reviver o tempo passado, através das suas lembranças, esses sujeitos as modificam todas as vezes em que relembram, pois a lembranças, assim como os homens, são mutáveis. Ao rememorar, os sujeitos presentificam e dão outros significados às suas lembranças a partir das suas experiências. Suas narrativas são como bumerangues, vão e voltam entre lembranças esquecidas ou apagadas, porque elas causam sentimentos parecidos com aqueles de outrora.

Se para os jovens sujeitos desta pesquisa retornar à infância causa inquietude, para seus pais deve causar, além disso, constrangimento ante o sonho frustrado. A maioria dos pais dos nossos jovens é formada por pessoas que sempre viveram "à margem da escrita", os "analfabetos", impulsionados para a cidade por conta da retórica do "progresso" e do desejo de dar aos filhos um futuro mais promissor. Por conta da ideia de "progresso" não se sentem em casa em lugar algum. Há sempre um desejo de voltar para o lugar de onde foram praticamente expulsos. Alguns dos pais dos nossos depoentes, anos mais tarde, quando os filhos já podiam seguir sem eles, conseguiram comprar um terreno e voltar para a floresta. Lugar para o qual, mesmo sentindo saudades da infância, nossos depoentes não querem voltar, pois afirmam que já se acostumaram com o cotidiano da "cidade".

Outra questão observada nas falas dos nossos depoentes é que, antes de entrarem na escola, o mundo do trabalho já fazia parte das suas rotinas; assim, a ida para a escola ampliava suas obrigações. Desde muito jovens, as crianças compartilhavam das obrigações familiares. A narrativa de Félix Cavalcante ilustra a questão.

Eu fui para escola muito cedo, meus pais sempre tiveram essa preocupação. Com seis anos eu já estava na escola. Tinha que estudar e trabalhar. A gente era de família carente, minha mãe começou a fazer quibes para vender. Eu ia para rua pela manhã, vender os quibes e, à tarde, eu ia para a escola (CAVALCANTE, 2013).

Félix afirma ser "de origem humilde" e seus pais pareciam acreditar que a educação era 
a salvação para a situação vivida. Ele não podia deixar de trabalhar para ajudar a família, mas também não podia abandonar a escola. Ao relembrar o início da sua vida escolar, observa que, enquanto o pai acreditava que não importavam as condições e que o filho deveria trabalhar, a mãe afirmava que ele precisava ir para a escola, mesmo em situações adversas. Assim, Félix se desdobrava entre a escola e o trabalho. Nessa fase da vida, relembra, com certo pesar e um riso entre os lábios, os momentos de dificuldades por ele vividos. A falta de alimentos e material escolar era frequente, mas isso não representava motivo para a desistência. Ele relata que, pela manhã, a mãe preparava um café preto para ele e o enviava para a escola, pois sabia que "no colégio tinha merenda" (CAVALCANTE, 2013). Félix descreve ainda que sua maior alegria quando criança era comprar um pacote de bolacha, pois "o pacote de bolacha era ideal para levar meu caderno, meu lápis e a borracha, que era um pedaço de sandália havaiana que a gente cortava" (CAVALCANTE, 2013).

Lendo seu relato, podemos pensar que essa era uma realidade daquele tempo, dos idos de 1991/92 e que, atualmente, tal situação já não se dá mais. Porém, Félix Cavalcante relata outra ocasião muito semelhante a essa. Entre suas lembranças, destaca um dos momentos mais difíceis experimentados por ele ao iniciar o Curso de Artes Cênicas - Teatro, no ano de 2010. Ele saiu da sua cidade natal, Tarauacá (AC), para frequentar o curso na capital rio-branquense.

\begin{abstract}
No primeiro período, eu pensei muito em desistir do curso. Pensei em trancar e voltar para casa, para os braços da minha mãe. Porque você sai do município que você tem uma estrutura, uma casa, um pai, uma mãe que lhe sustenta, que lhe dá apoio e você vem para um canto que você não tem ninguém e você não conhece ninguém. A fome que a gente passa, a falta de moradia, o dormir no chão, porque você não tem onde dormir. Até você se estabilizar... Eu acho que isso foi uma das maiores... [dificuldades]. Foi uma das maiores [dificuldades] que eu enfrentei. Tem dia que você olha... Eu queria $\mathrm{R} \$ 1,50$ para comer no RU (Restaurante Universitário) da UFAC e não tinha. Dava vontade de arrumar as malas e voltar. Eu morava com meu colega e um dia a gente abriu a geladeira e tinha um copo de suco. Eu disse: eu tomo a metade e tu toma a metade. Isso numa sexta-feira, passamos o sábado e o domingo só tomando água. 'Ai, meu Deus, se aparecesse alguém aqui (risos), pelo menos oferecer um quibe pra gente' (CAVALCANTE, 2013).
\end{abstract}

Entre o riso escancarado e um sentimento de pesar, Félix Cavalcante se dá conta de que não podia contar com a ajuda dos pais, pois a decisão de vir para Rio Branco havia sido dele. Os pais continuavam vivendo em situação de "carência" em Tarauacá. Ele se mudou para a capital sabendo que os pais não teriam condições de apoiá-lo da mesma forma que o apoiavam em sua cidade natal. Em Tarauacá, ele morava com os pais e fazia teatro. Era um sujeito envolvido com as questões políticas e acreditava que podia mudar de vida através da política. Ao perseguir o sonho de cursar o ensino superior, de aprimorar sua experiência teatral na universidade, ele se deparou com espectros da sua infância. Outrora, era apenas um menino que vendia quibes em sua cidade, no momento de suas lembranças ele desejara somente ter um daqueles quibes para comer.

A infância pobre que viveu the perseguiu durante o primeiro semestre do curso, e isso foi motivo suficiente para ele pensar em desistir. Apenas continuou o curso porque logo conseguiu um trabalho e já na primeira semana recebeu seu primeiro salário. O trabalho foi para ele a afirmação da sua “condição humana". Não recebeu da universidade nenhum tipo de assistência estudantil e, diferentemente do que acontecia na escola, não havia na universidade a "merenda escolar".

Não queremos responsabilizar a universidade por todas as dificuldades vividas por Félix Cavalcante e outros tantos desistentes em razão das circunstâncias. No entanto, acreditamos que a dificuldade por ele encontrada poderia ter sido minimizada se tivesse acesso à informação necessária para buscar os setores de auxílio estudantil. É nesse sentido que Camila Cabeça direciona sua fala.

O saber fazer a universidade eu acho que é o que falta, uma educação universitária para as pessoas compreenderem que tem uma carreira dentro da universidade que você pode fazer, que você pode seguir. Muitos alcançam, outros não. A maior dificuldade foi fazer a própria universidade. Eu sou 
aluna do começo do curso. Eu já fiz 70\% do meu curso, mas ainda falta [uma parte]. Eu deixei muitas [disciplinas por fazer] porque eu tinha que trabalhar. Foi mais assim, eu não tinha recursos, computador que você precisa ter. Recursos, recursos. Gente, eu demorei muito para entrar na biblioteca. Deveria ter uma disciplina só disso (CABEÇA, 2013).

A falta de informação foi sentida e comentada por Camila Cabeça, que, assim como todos os outros, precisou se desdobrar entre a universidade e o trabalho, principalmente, porque desconhecia a universidade. A jovem precisou trabalhar e estudar: somente estudar, embora fosse desejado, estava fora das possibilidades, pois, além de enfrentar as dificuldades financeiras, tinha de lidar com sentimentos de culpa por ter entregado a filha para morar com o pai, em Belém do Pará.

É o "tempo passado" que retorna, tempo medidor de distâncias, de pessoas, de lembranças. Aquele "tempo" se faz presente, ele faz parte de lembranças que são apenas "um detalhe, muitos detalhes, eis o que são as lembranças. Cada uma delas, quando se destaca tecida de sombra, é relativa a um conjunto que lhe falta" (CERTEAU, 2011, p. 150). Sombra que assombra e amedronta aqueles que experimentaram o que costumamos chamar de traumas, os quais, segundo Barthes (1990), demonstram a interrupção da linguagem e, logo, a incapacidade de comunicar. Traumas ocasionados por processos de ruptura por vezes perceptíveis, por vezes invisíveis.

$\mathrm{Na}$ narrativa de Jobson Costa notamos uma constante recusa quando perguntado sobre sua vida no "tempo passado". Ele afirmou "eu não lembro bem, eu não tenho muita memória", repetidas vezes ele nos disse "tenho memória de pouca coisa assim..." e ainda "algo que eu não tenho na minha memória" (COSTA, 2013). Diante da recusa em rememorar, nosso sujeito entra em conflito consigo mesmo. Em um dos momentos, ele deixou escapar aquilo que tentou esquecer: "acho que não lembro porque eu queimei a casa. Esqueci tudo da minha vida daí para trás” (COSTA, 2013). Acidentalmente, ele provocou um incêndio na sua casa no momento em que estava sozinho com seu irmão novo. Casa que se foi juntamente com as imagens fotográficas da sua família. Todas as "lembranças" familiares viraram cinzas assim como a casa. Dessa forma, ele as "esqueceu". Tentou esquecer aquilo que ocasionou a culpa carregada por ele durante toda a vida.

Culpa ratificada pela acusação dos seus familiares que sempre insistiram em afirmar, recontar e negar as responsabilidades deles, pois não aparecem nas lembranças do jovem qualquer manifestação de culpa daqueles que o deixaram sozinho em casa com quatro ou cinco anos de idade, na companhia de um bebê. A consequência, no caso desse jovem, foi ter a casa queimada e, assim, uma família dividida, pois todos os parentes moravam juntos no mesmo casebre de madeira construído próximo ao barranco do rio e tiveram de se mudar após o acontecimento. Barranco que também os fazia conviver com as enchentes do rio Acre.

Enchentes que simbolizavam para nossos depoentes a alegria de ter água no quintal de casa ou mesmo de ter alagadas as ruas do bairro. Imagem essa muito presente no imaginário daqueles que conhecem o rio e sua beleza que desaloja. Para a criança de outrora, aquelas águas próximas à porta de casa nada mais eram do que diversão, mas para seus pais eram uma preocupação. Por isso, a nova casa de Jobson Costa foi construída aproximadamente dois metros acima do nível da rua e, embaixo da casa, era mantida uma canoa, meio de transporte utilizado durante a alagação. Alagação que não obedece aos comandos humanos. É um rio que corre e enche no seu ciclo natural; é o rio, o lugar de passagem e transporte dos homens.

Valter Frazão também relata suas experiências com o rio de águas turvas. Ele conta que, quando o rio enchia, o refúgio era sempre a casa de parentes próximos. Aliás, foi na casa de parentes que o jovem passou a maior parte da sua infância. Foram esses parentes que o levaram para a escola pela primeira vez. Ele não teve escolha. A escola era obrigação e, com ela e através dela, se viu obrigado a 
sair da casa da mãe. Também em sua história de vida, a casa de parentes foi o caminho mais curto para a escola: "quando eu mudei e fui morar com minha tia, eu já comecei a estudar" (FRAZÃO, 2013). Ao sair da casa da tia, foi morar com a avó e, somente quando estava prestes a terminar o Segundo Grau, atual Ensino Médio, voltou a morar na casa mãe. O que ele ouvia o tempo todo era a cobrança de que precisava concluir seus estudos a qualquer custo.

As cobranças familiares em relação à sua vida escolar cessaram quando terminou o segundo grau. Sua família já não se importava com a continuação dos estudos, afinal, concluindo o segundo grau, ele já poderia conseguir um trabalho. E foi isso que fez, começou a trabalhar no comércio de Rio Branco. Era um rapaz jovem, tinha apenas 19 anos quando enfim conseguiu "concluir os estudos" e não deu continuidade aos mesmos. Valter Frazão relata que não fazia ideia do que era um curso superior, isso em 2004. Para ele, não havia perspectivas, não havia opções para continuar os estudos. Não era motivado em casa e nem ao menos sabia o que era uma universidade.

Somente quando começou a trabalhar no comércio, sua patroa o alertou sobre a possibilidade de continuar seus estudos, mencionou o ensino superior, ressaltando que ele ainda era jovem e poderia prestar o vestibular. Depois disso, Valter Frazão procurou se informar. Em 2006, fez o vestibular para economia, mas não obteve êxito. Em 2007, foi aprovado na seleção para o Curso de Artes Cênicas - Teatro.

A narrativa de Valter Frazão pode causar estranhamento para a grande maioria das pessoas na atualidade. Afinal, como aceitar que, em 2004, ao concluir o Segundo Grau, um jovem não soubesse que poderia continuar seus estudos? Em um tempo em que as mídias invadem nossas casas, em que os professores são estimulados a incentivar os alunos a continuar os estudos, em que o vestibular foi substituído pelo Exame Nacional do Ensino Médio, o ENEM, isso nos parece improvável. Entretanto, vale ressaltar que essa ainda é a "realidade" de muitos que não têm facilidade de acesso a informações.

Keyssânia Muniz também compartilha das experiências vividas por Valter Frazão ao afirmar "eu era muito perdida, totalmente leiga, eu era totalmente desinformada mesmo, vamos dizer assim, eu nem sabia o que significava UFAC” (MUNIZ, 2013).

Ainda hoje, podemos nos deparar com histórias semelhantes a essas, principalmente, porque as informações não são acessíveis a todos. Há locais em todo o Acre em que os jovens são privados de informação. Muitos nem ao menos se sentem estimulados a concluir o Ensino Médio, porque não sabem no que lhe será útil. Outros, mesmo querendo continuar seus estudos, não têm a oportunidade de escolha, visto que o número de vagas e cursos de ensino superior é insuficiente. Como se não bastasse, os jovens se veem obrigados a realizar o ENEM e, com as notas que alcançam, geralmente baixas e insuficientes para concorrerem ao curso que desejam, precisam se adequar a uma das vagas que, "gentilmente", a eles é oferecida.

Nossos depoentes, que ingressaram no curso por meio do vestibular, tiveram a oportunidade de escolher antes da prova o curso que desejavam frequentar. Destacamos que a escolha pelo Curso de Artes Cênicas - Teatro aconteceu por diversos motivos. Alguns definiram sua opção em função da afinidade com a arte, outros acreditaram que era o curso mais provável de alcançarem a aprovação no vestibular. Foi o caso de Andrea Gomes:

Meu sonho era entrar aqui na UFAC. Não importava como... Eu lembro que surgiu o curso. Fui ler o edital, é claro, para saber do que se tratava, porque eu nunca nem tinha ouvido falar em artes cênicas. Eu nunca nem imaginava ser professora de artes. (...) Na verdade, eu vou ser bem sincera, eu fiz, me inscrevi no curso, assim, na doida, porque, como era a terceira vez que eu prestava vestibular, eu não estava mais na expectativa de passar e tal. Foi o vestibular que eu fiz mais assim... por fazer. Aí eu nem sabia que tinha passado, uma menina que me ligou e disse que eu tinha passado e, depois de três dias, fui olhar. Pra tu ver meu interesse. Eu disse: 'ah, passei!' (GOMES, 2013). 
Embora fosse um sonho alimentado na escola e não importasse por quais meios ela ingressasse na UFAC, Andrea Gomes não demonstrou grandes expectativas quando soube da sua aprovação. Anteriormente, ela nem ao menos sabia da existência do curso. Nunca havia atentado para a possibilidade da existência de um curso de artes cênicas, não sabia nem o que significava, muito menos havia cogitado a possibilidade de se tornar professora de arte.

Afinal, recorda que, durante toda sua vida escolar, a prática artística na escola era inexistente. Seus professores de arte costumavam chegar à sala, se apresentar e sugerir pesquisas bibliográficas sobre artistas que ela somente conhecia por meio dos próprios esforços. A arte na escola era um passatempo, uma complementação curricular. Não era levada a sério e, portanto, não sabia que poderia ser encarada como uma profissão com formação superior. Mas, no ato da inscrição no curso, Andrea Gomes apenas vislumbrava a possibilidade de ingressar na universidade, pois todos os universitários que ela conhecia sentiam orgulho de estar da "federal". Ela havia percebido que a "pessoa mudava o estilo se entrasse na UFAC" (GOMES, 2013). A pessoa se transformava e era isso que ela almejava, queria poder se orgulhar de também estar na "federal" e mudar de estilo, quiçá de vida.

Ao adentrar os muros universitários para realizar seu sonho, Andrea Gomes se deparou com algumas dificuldades e destaca uma delas:

Não tinha bloco [prédio do curso], faltavam professores e quando surgiram os professores eles não supriam as nossas expectativas. Eu achei, alguns, é claro, muito prepotentes, tipo subestimando a gente que é aqui do Acre e tal. Eles vieram com a bagagem e chegaram aqui achando que eles eram os caras. Foi isso que eu senti (GOMES, 2013).

Embora ressalte a inexistência do bloco do curso de arte no início da faculdade, o que mais a marcou foi o fato de sentir, entre outras questões, que os professores negavam os saberes dos alunos em prol das experiências que os docentes viveram nos lugares de onde vieram. Não havia, portanto, a desculpa da "falta de bloco", conforme constata Maria Francisca, "a gente não tinha sala para estudar, pois não precisa ter uma sala de aula, basta ter um espaço e a gente querer” (SILVA, 2013). Assim, algumas das maiores dificuldades enfrentadas durante suas trajetórias foram as de se relacionar, de se envolver, de estabelecer contato, de dialogar.

Valter Frazão observa:

Se relacionar com os professores foi para mim a maior dificuldade. Que logo de cara, pelo menos eu acho que todos encararam isso, não é? Pelo menos a maioria, pois, em vez, do professor dar, pelo menos, sua própria aula, mas não, ele já quer fazer o aluno desistir, desencorajar do curso. O que não é função dele (FRAZÃO, 2013).

A generalização feita pelo depoente, quanto à dificuldade de se relacionar com os professores, faz sentido, pois ele viveu essa situação em grupo, nas turmas de estudantes pelas quais transitou. Os discursos eram sempre os mesmos: os professores não sabiam lidar com a resistência dos alunos e a "apatia" das turmas. Se os alunos não faziam as atividades de acordo com a vontade dos professores, logo vinha a fala desencorajadora, conforme citada por Alan Saldanha.

Nossos depoentes relembram que chegaram a se decepcionar com o curso e, em muitos momentos, pensaram em desistir: "Eu pensei em desistir, mas aí eu pensei, eu vou desistir e perder esse tempo todo que eu fiquei aí dentro, para começar outro curso do zero? Aí eu disse 'não, vou concluir!"' (FRAZÃO, 2013). No decorrer do processo, alguns perceberam que o curso não era o que desejavam como formação superior, mas, depois de um tempo, "não sabem como", passaram a defender o curso e a linguagem artística da sua futura formação e profissão.

Acreditamos que o sujeito assume o discurso favorável à sua formação, pois, em geral, tudo que ele lê na sua graduação é referente ao curso no qual está sendo formado. São representações de 
mundo que é levado a incorporar. A isso se deve sua aprovação e a conclusão da sua jornada acadêmica. Durante a graduação, os sujeitos são condicionados "porque tudo aquilo com que eles entram em contato torna-se imediatamente uma condição de sua existência" (ARENDT, 2010, p. 10).

No depoimento de Maria Francisca da Silva, notamos como ela se envolveu com o que teve contato durante os anos da sua graduação:

O teatro é minha vida. Minha alma. No teatro eu consigo fazer tudo. Não me imagino mais sem teatro, sem história, não me imagino sem contar uma história para uma criança, para uma avó, para um avô. Eu não sei o que eu seria, eu seria inútil talvez, e eu não quero ser inútil, eu quero ser útil. Eu quero fazer alguma coisa. E eu gosto disso, não tem para onde correr. É tudo o teatro, a música, a dança, a história, é tudo. Eu não quero parar (SILVA, 2013).

A jovem incorporou o discurso. É assim que os indivíduos têm sua subjetividade transformada ao ingressar em um curso de ensino superior. A defesa do curso é "forjada" e o aluno o defende, pois, embora não perceba, ele foi formado para isso. Ao sair da academia, seus discursos são reflexos da sua formação acadêmica. Defende sua área de formação e afirma sentir orgulho da sua profissão. Ressaltamos que o sujeito tem seu corpo transformado juntamente com o discurso, mas ele, talvez, não se dê conta disso. As mudanças parecem ocorrer somente no pensamento. Relaciona-se o pensamento ao conhecimento adquirido durante a graduação. Como se o corpo e o pensamento fossem dois elementos distintos.

Nas palavras de Elton Castro, "durante o curso, a gente se transforma" (CASTRO, 2013). No entanto, não percebemos em qual dimensão essa transformação ocorre, afinal, queremos ser indivíduos únicos e exclusivos, mas somos constituídos a partir do discurso do outro, é o outro que diz quem nós somos. É o outro quem nos forma. Geralmente, nossos discursos de licenciados em artes cênicas - teatro são constituídos para que defendamos as ideias dos outros. Não criamos durante a graduação, nós reproduzimos conceitos, normas e valores. Continuamos como sujeitos incompletos, formados em apenas uma linguagem, incapazes de visualizar o todo. Nossas falas são marcadas por outras falas, com as quais dialogamos o tempo todo, mas, muitas vezes, usamos as falas como se fossem nossas, como uma tentativa de supervalorização do eu.

Observamos isso na declaração de Maria Francisca da Silva: "eu não quero ser inútil". Para nós, está claro que ela entende que tem o dever de fazer algo pela humanidade através da arte com a qual teve contato durante os anos de graduação. Como ela aprendeu isso? Através dos valores morais com que conduz sua vida e com os quais não consegue romper. Essa não é uma dificuldade apenas de Maria Francisca da Silva, mas de todos nós. Somos conduzidos pelo sentimento da moral e pelo dever da obediência (NIETZSCHE, 1977). Assim, é no decorrer da formação acadêmica que os sujeitos são encaminhados para um lugar-comum, um lugar pertencente à linguagem da formação. O sujeito é literalmente enquadrado nesse lugar e dele não consegue sair caso não seja capaz de visualizar a complexidade desse processo: ele precisa perceber onde está, para, então, romper.

No processo de formação, há sempre aqueles que resistem, que "fingem" a incorporação de certos saberes, que se colocam no lugar para o qual estão sendo preparados. Eles percebem para onde estão sendo conduzidos e "se deixam levar" para conquistar o diploma. Em síntese, não são seres encapsulados, lançando mão de "táticas" de sobrevivência muito comuns nas sociedades contemporâneas. Desse modo, é importante destacarmos que a fala de Maria Francisca da Silva se dá em um jogo de representação e, como tal, pode ser uma das suas táticas, uma maneira de nos dizer aquilo que "talvez" ela supunha que queríamos ouvir. Como futura licenciada, é seu dever gostar de teatro e não mais saber viver sem ele.

Durante a pesquisa, percebemos que uma das "táticas" utilizadas pelos alunos ao lon- 
go do curso é o silêncio e a ação. Diante dos comandos dos professores nas aulas práticas, onde o corpo se torna o objeto de trabalho e manipulação, os alunos se movimentam silenciosamente e, na hora de compartilhar suas sensações, superações e dificuldades, eles silenciam. Silenciam, talvez, porque já compreenderam que o silêncio, às vezes, é o que mais incomoda aqueles que os comandam. Silenciar é também transformar, re-significar (ORLANDI, 2007). Os sujeitos que silenciam, que se calam e apenas fazem o que é solicitado não são apenas espectadores passivos: em silêncio promovem transformações. Nesse sentido, para nós, observadores do espaço e das práticas, o silêncio é uma das "mil maneiras de jogar/desfazer o jogo do outro" (CERTEAU, 2011, p. 74).

Frente ao silêncio ensurdecedor, professores questionam os alunos: "é isso que vocês realmente querem?". Nessa fala que vai e volta durante toda a formação, notamos a incapacidade dos professores de perceber as táticas utilizadas pelos sujeitos que não reclamam. Eles apenas fazem, se movimentam, improvisam, fingem superar suas limitações físicas em prol da avaliação. Entendem que é preciso "fazer só isso e depois estará tudo certo" (SALDANHA, 2013).

Dentro do quadrado branco, os professores são avessos às trajetórias dos sujeitos que “optam" pelo Curso de Artes Cênicas - Teatro. Tudo que o aluno fez dali para trás não importa. Interessa dali para frente. No universo das ideias, os alunos continuam sendo apenas números. Números de matrícula, RG, frequência, estatísticas. Os alunos talvez percebam isso. Notam, não sem conflito, que a eles cabe obedecer, pois foi isso que aprenderam na escola. Daí vem o silêncio. Calar diante do que é dito pode ajudar esses indivíduos a concluir o curso e assim, possivelmente, superar suas próprias limitações e se tornarem professores. As motivações para concluir o curso não estão relacionadas ao "poder da educação", ou à faculdade, ao Estado, ao mercado de trabalho ou aos professores. Suas motivações para conclusão do curso estão totalmente vinculadas às suas próprias trajetórias de vida.

Nessa direção, o relato de Félix Cavalcante é muito significativo:

Eu vejo muito os meus pais. Meu pai hoje com 52 anos, para sobreviver, para ter uma vida tranquila, para não passar fome, ele tem que passar o dia no sol quente em uma bicicleta cargueira, carregando. Fazendo frete em uma bicicleta. Minha mãe tem 55 anos, ela tem que fazer cocada para vender para se manter. Então, cada dia que passa eu penso nisso: eu tenho que concluir o curso, eu tenho que passar no concurso, eu tenho que ajudar os meus pais. Eu acho que motivação mesmo são os meus pais (CAVALCANTE, 2013).

Compartilhando da narrativa de Félix, Elton Castro e Keyssânia Muniz também pontuam a mesma motivação. Suas experiências traumáticas e o desejo de não revivê-las é o que os faz continuar. Para esses sujeitos, a motivação está nos pais, a luta diária desses que os guiaram, que os conduziram entre sonhos irrealizados. Sonhos esses materializados na possibilidade de os filhos concluírem o ensino superior, para não serem como eles e, assim, não terem a vida toda marcada pelas dificuldades para sobreviver.

Para nossos depoentes, os pais são os verdadeiros merecedores da conquista e é para honrá-los, para fazer "valer a pena" o esforço que tiveram ao enviá-los à escola que esses jovens prosseguem. Eles não concluirão a etapa com o diploma, mas com a docência, com a aprovação em um concurso público, o lugar mais seguro que foi dado a eles durante o curso. Também durante suas trajetórias acadêmicas, as outras possibilidades de profissão anunciadas no edital foram afastadas. Aprenderam ser a docência na escola pública a possibilidade de retorno financeiro. Afinal, durante o curso, um argumento recorrente é o "farto mercado de trabalho" existente para os professores de arte no estado do Acre, pois "são mais de duas mil vagas para professor de arte em todo o estado". Esse é o discurso motivacional utilizado com frequência por seus professores.

A profissão inicialmente rejeitada é incorporada como parte das idealizações dos su- 
jeitos. Suas expectativas então são "passar em um concurso do estado, ser professor" (FRAZÃO, 2013). Fala recorrente dos nossos depoentes que demonstram a aceitação do discurso tantas vezes repetido dentro da sala de aula. "Porque ser professor é o caminho mais perto. Porque eu estudei, e é claro que a gente pensa em um emprego, ou tu acha que eu vou estudar e vou atrás de um emprego lá no centro para ser camelô?” (FRAZÃO, 2013). No final das contas, todos parecem estar seduzidos pela segurança do serviço público.

Mas não é apenas a sala de aula que aparece nos horizonte dos sujeitos de nossa pesquisa, como pode ser apreendido na narrativa de uma de nossas depoentes: "sou contra ir para sala de aula" (CABEÇA, 2013). O desejo de Camila Cabeça é trabalhar com projetos, com a dança, com o teatro. Quer ter contato com empresas, quer fazer pesquisa e continuar o ciclo que iniciou em Belém do Pará, sua terra natal, "com o rodopiar da saia na dança do carimbó". Deseja conhecer outros artistas com quem possa experimentar novos projetos e trocar conhecimentos. Para ela, não há apenas a possibilidade da sala de aula, ela se recusa a ser professora, ela deseja os palcos.

Os sujeitos da nossa pesquisa vivenciam as mesmas leituras, têm contato com os mesmos professores, são formados de acordo com os mesmos parâmetros, entretanto, não agem ou pensam da mesma forma. É nessas relações culturais, existentes dentro da academia que percebemos a cultura como modo de vida. As vivências experimentadas no mundo acadêmico são semelhantes àquelas da vida em sociedade. O indivíduo aceita e recusa vivências de acordo com seus interesses e suas possibilidades no fazer-se cotidiano de suas práticas culturais.

Nossos depoentes dialogam com as experiências vivenciadas nos muros acadêmicos, com o silêncio a que são submetidos e com as violências simbólicas sofridas durante a formação. Nos encontros/desencontros, eles podem falar, embora muitos, em seus silêncios, nos confessem que sabem, "mas não pode[m] dizer alto" (CERTEAU, 2011, p. 72). Falam das suas experiências, dos seus anseios, dos seus medos e das atitudes tomadas por eles durante a formação. Nesse processo de escuta, nos sentimos privilegiados ao ouvir as "confidências" dos nossos depoentes, uma vez que "nem sempre proclamamos em voz alta o que temos de mais importante a dizer. E, mesmo em voz baixa, não o confiamos sempre a pessoa mais familiar, mais próxima e mais disposta a ouvir a confidência" (BENJAMIN, 1994, p. 40). Sabemos que muitas "coisas" deixaram de ser compartilhadas por falta de segurança em si mesmos e em nós. Mas o que nos foi dito faz parte do corpo dos nossos depoentes. As marcas são visíveis mesmo quando não são comunicáveis.

O diálogo foi estabelecido com sujeitos que se envolveram e foram envolvidos pelo sistema acadêmico. Não nos interessou, desse modo, defender o bem ou o mal, afinal, tudo isso é, também, uma invenção humana, um discurso produzido. O desafio aqui foi estabelecer um diálogo com as ambiguidades. Sendo assim, o que apresentamos são as particularidades, as singularidades, os pontos de vista, apenas partes do corpo dos sujeitos que se tocam e são tocados durante o processo formativo. Aqui estão expostas pequenas partes do que foi vivido e, aqui, foi narrado, lembrado, contido. São as inscrições corpóreas do passado.

Diante da complexidade das vivências analisadas, das ambiguidades presentes, da ambivalência constante no objeto, das incertezas, nos resta "apenas" defender o que há de mais essencial para os sujeitos: o direito de viver, experimentar, aprender fazendo e errando. Deixemos que os sujeitos falem das suas experiências, do que eles viveram ou da forma como eles leram. Resgatamos o direito de comunicar, contar histórias, teorizar não somente com aquilo que os homens do saber acadêmico disseram, mas com aquilo que os estudantes viveram. Abrindo espaços para suas narrativas sobre o "real vivido", talvez possamos encurtar as fronteiras "entre os mestres e os ignorantes". Afinal, eles, os alunos veem, leem, vivem e se comunicam. Mesmo ao observar em silêncio eles agem. Ser espectador "é nossa 
situação normal. Aprendemos e ensinamos, agimos e conhecemos também como espectadores que relacionam a todo instante o que veem ao que viram e disseram, fizeram e sonharam" (RANCIÈRE, 2012, p. 21).

\title{
SILENCING, EDUCATION AND PERFORMING ARTS: THE EMPTYING OF EXPERIENCE
}

\begin{abstract}
This article takes as a starting point narrated memories and gestures, and their constant dialogue with educational experiences, in order to highlight the silencing processes embedded within specific training practices and patterns, in the context of the Course of Performing Arts - Theatre at the Universidade Federal do Ace. Using cultural studies as a reference, this work dialogues with speeches characterised by constant tensions between lecturers and students, underscored by vertically hierarchic relations within the classroom. What becomes apparent through these encounters between different experiences is the fact that school, and university in this case, play a crucial role in the transformation of human memories and subjectivities, disrupting bodies in contexts in which experience is diminished over the theoretical knowledge that needs to be learned by the end of the course.
\end{abstract}

\section{PALAVRAS CHAVE}

Body. Trajectory. Memory. Silencing. Experience

\section{REFERÊNCIAS}

ARAÚJO, D. Entrevista concedida a Vanessa Nogueira de Oliveira. Rio Branco, 8 jul. 2013. (Diana de Araújo Barbosa).

ARENDT, H. A condição humana. Tradução de Roberto Raposo. 11. ed., Rio de Janeiro: Forense Universitária, 2010.

BARTHES, R. O óbvio e o obtuso: ensaios críticos III. Tradução de Léa Novaes. Rio de Janeiro: Nova Fronteira, 1990.

BENJAMIN, W. Magia e técnica, arte e política: ensaios sobre literatura história da cultura. Tradução Sérgio Paulo Rouanet. 7. ed., São Paulo: Brasiliense, 1994.

CABEÇA, C. Entrevista concedida a Vanessa Nogueira de Oliveira. Rio Branco, 18 jul. 2013. (Camila Cristina Cabeça de Souza Lima).

CARDIM, L. N. Corpo. São Paulo: Globo, 2009.

CASTORIADIS, C. A instituição imaginária da sociedade. Tradução de Guy Reynaud. Rio de Janeiro: Paz e Terra, 1982.

CASTRO, E. Entrevista concedida a Vanessa Nogueira de Oliveira. Rio Branco, 10 jul. 2013. (Elton Castro da Silva).

CAVALCANTE, F. Entrevista concedida a Vanessa Nogueira de Oliveira. Rio Branco, 16 jul. 2013. (Félix Cavalcante da Silva).

CERTEAU, M. A cultura no plural. Tradução de Enid Abreu Dobránszky. Campinas, SP: Papirus, 1995.

CERTEAU, M. A invenção do cotidiano: artes de fazer. Tradução de Ephraim Ferreira Alves. 17 ed. Petrópolis, RJ: Vozes, 2011.

COSTA, J. Entrevista concedida a Vanessa Nogueira de Oliveira. Rio Branco, 9 jul. 2013. (Jobson Costa de Souza). FOUCAULT, M. Vigiar e punir: nascimento da prisão. Tradução de Raquel Ramalhete. Petrópolis: Vozes, 1987.

FRAZÃO, V. Entrevista concedida a Vanessa Nogueira de Oliveira. Rio Branco, 8 jul. 2013. (Valter Frazão da Silva).

GLISSANT, E. Introdução a uma poética de diversidade. Tradução de Enilce Albergaria Rocha. Juiz de Fora (MG): Editora da UFJF, 2005.

GOMES, A. Entrevista concedida a Vanessa Nogueira de Oliveira. Rio Branco, 8 jul. 2013. (Andrea Gomes do Nascimento).

HALL, S. Da diáspora: identidades e mediações culturais. Tradução de Adelaine La Guardia Resende e outros. Belo Horizonte: Editora da UFMG, 2003.

KOTHE, F. R. Ensaios de semiótica da cultura. Brasília: Ed. Universidade de Brasília, 2011.

MUNIZ, K. S. Entrevista concedida a Vanessa Nogueira de Oliveira. Rio Branco, 7 fev. 2014.

NIETZSCHE, F. W. Além do bem e do mal ou Prelúdio de uma filosofia do futuro. Tradução de Márcio Pugliesi. São Paulo: Hemus, 1977. 
ORLANDI, E. P. As formas do silêncio: no movimento dos sentidos. Campinas, SP: Editora da Unicamp, 2007. PORTELLI, A. A filosofia e os fatos: narração, interpretação e significado nas memórias e nas fontes orais. Revista Tempo. Rio de Janeiro, v. 1, n. 2, 1996, pp. 59-72.

PORTELLI, A. Forma e significado na história oral: a pesquisa como experimento em igualdade. Revista Projeto História. São Paulo, n. 14, fev. 1997.

PORTELLI, A. Memória e diálogo: desafios da história para a ideologia do século XXI. In: ALBERTI, V.; FERNANDES, T. M.; FERREIRA, M. M. História oral: desafios para o século XXI. Rio de Janeiro: Ed. Fiocruz, 2000. PORTELLI, A. Tentando aprender um pouquinho: algumas reflexões sobre a ética na história oral. Revista Projeto História. São Paulo, n. 15, abr. 1997.

RANCIÈRE, J. O espectador emancipado. Tradução de Ivone C. Benedetti. São Paulo: Editora WMF Martins Fontes, 2012.

SALDANHA, A. S. Entrevista concedida a Vanessa Nogueira de Oliveira. Rio Branco, 10 jul. 2013.

SILVA, M. F. P. Entrevista concedida a Vanessa Nogueira de Oliveira. Rio Branco, 23 out. 2013.

WILLIAMS, R. Cultura e sociedade: 1780-1950. Tradução de Leônidas H. B. Hegenberg e outros. São Paulo: Companhia Editora Nacional, 1969.

Data de recebimento: 27/02/2016

Data de aceite: 29/04/2016 